\title{
Complexity-Based Pedagogy for E-Learning: Description of Emergence in a Graduate Nursing Program
}

\author{
Gail J. Mitchell, F. Beryl Pilkington, Isolde Daiski, Nadine Cross \\ Faculty of Health, School of Nursing, York University, Toronto, Canada \\ Email: gailm@yorku.ca
}

How to cite this paper: Mitchell, G.J., Pilkington, F.B., Daiski, I. and Cross, N. (2017) Complexity-Based Pedagogy for ELearning: Description of Emergence in a Graduate Nursing Program. Open Journal of Nursing, 7, 222-241.

https://doi.org/10.4236/ojn.2017.72019

Received: January 4, 2017

Accepted: February 21, 2017

Published: February 24, 2017

Copyright $\odot 2017$ by authors and Scientific Research Publishing Inc. This work is licensed under the Creative Commons Attribution International License (CC BY 4.0).

http://creativecommons.org/licenses/by/4.0/

\begin{abstract}
This paper describes the kind of engagement and emergent learning that happened in three different sections of a graduate nursing course. Three nursing educators used an e-learning platform called Daagu that was developed by faculty guided by complexity pedagogy. A total of 43 students were enrolled in the full credit foundations course in theory and philosophy. Authors describe two specific instances of emergent learning: one was expressed by students in relation to a particular resource (article, TedTalk, YouTube, Poem) or discussion, and the second is in relation to specific "aha moments" or shifts in understanding that changed student attitudes and actions. Quotes of emergent learning provide a source of narrative data for conversing about and developing quality e-learning platforms for students and educators.
\end{abstract}

\section{Keywords}

Nursing Education, Complexity Pedagogy, Emergence, E-Learning

\section{Introduction}

Many educators want to participate in educational experiences that are meaningful, engaged, and transformative. Mureşan [1] directs our attention to the reality that networked/participative learning and Web 2.0 technologies enhance educational opportunities and some authors propose that educators have a responsibility to be innovative when it comes to teaching-learning [2]. The platform being described in this research addresses the need for expanding e-learning opportunities for students and faculty. The platform is called Daagu and is based on a complexity pedagogy that enables student engagement, choice, expression of diverse views, emergent learning, and personal discovery. The purpose of this research report is to present findings from a qualitative analysis of 
three different sections of a graduate nursing course taught by three educators using the complexity e-learning platform. Findings show how complexity pedagogy in an e-learning format enabled student engagement, emergent learning, and application of knowledge in new ways. We begin with a brief background on e-learning in higher education.

\section{E-Learning in Higher Education}

Numerous universities across North America are marketing higher education programs for students looking for flexibility and accessibility. Canada has a Virtual University at http://www.cvu-uvc.ca/courses.html offering links to hundreds of degrees and thousands of courses, and there are similar organizations in Australia, the United Kingdom, and United States. Although availability of higher education is clearly present via the Internet, what is not as clear are the pedagogical approaches offered to students in these rapidly developing courses and programs.

Current educational experiences for many students and teachers have been informed by a content driven, teacher as expert pedagogy that has created generations of learners who look to experts to tell them what they need to know and how they should learn what is needed [3] [4] [5]. Informed by Tyler [6] and advanced by behaviourist thinking, the content driven approach typically predefines learning objectives, preselects learning material, and arranges content in linear sequences for standardized delivery. A significant limitation of this approach is that students learn to figure out what faculty want, and give the content back without necessarily changing their knowledge, attitudes, and perspectives. The content driven, linear sequencing of curriculum is present in many e-learning platforms available to faculty and students [7]. Oftentimes, teachers take content and place it in PowerPoint slides, with or without voiceover technology and digital streaming, and deliver their content in the usual teacheras-expert formats with pre-defined learning outcomes. Although university students want e-learning, the major barrier to satisfaction is lack of interaction and engagement [8]. Meaningful engagement is essential to quality education.

There are some notable exceptions to the content driven, linear approaches in teaching. Some groups of educators from various countries are using constructivist [9] [10], connectivist [7] [11] [12], and complexity [3] [5] [13] [14] theories of learning to construct curricula. Although work has been advanced in e-learning constructivist pedagogies, through the Community of Inquiry [9] [10], for instance, there is not yet a coherent e-learning platform informed by complexity pedagogy. One exception to the lack of e-learning in complexitybased education is the work done by Morgan and Adams [15] in leadership education for health professionals. Educators and researchers looking for innovation aligned with new theories, such as complexity, are more often chiseling together learning management systems (LMS) with pre-existing social and networking software. Thus, in the literature one can find constructivists and connectivits using Moodle (an open source LMS) with Wikis, Blogs, Twitter, Face- 
book, and gRSShopper [7] in order to integrate the WWW and provide connections and nonlinearity for learners (see for example, [16].

Evidence from research investigating various pedagogies is not well established [17]. As these and other authors note, more research is needed in order to better understand what learning and what teaching actually benefit students. There is evidence supporting the effectiveness of and satisfaction with web-based learning [18]-[23]. Boling, Hough, Krinsky, Saleem, and Stevens [24] affirmed that students preferred courses that are more interactive and that include multimedia for teaching-learning. But as noted by others, enhanced technology without a change in pedagogy does not alter student experiences [25]. Price and Kirkwood [25] contend there is limited evidence to demonstrate that educators have changed their teaching practices with the introduction of technology, and if they have, how those changes influence the teaching-learning experience. Educators indicate that technology that helps meet students need is more compelling for change, but time and limited resources make changes in actual teaching practices unlikely. Further, many educators have not had opportunity to study and incorporate principles from the emergent pedagogies (constructivism, connectivism, and complexity) that all require student engagement and teacher facilitation in imaginative and meaningful inquiry [13] [24].

The technology (Daagu) used in this research offers a pedagogy informed by complexity thinking for web-based delivery in blended or fully online formats [26] [27]. Curriculum informed by complexity thinking may foster provocative and divergent thinking, deep understanding, and innovative insights that emerge in community discussions [28] [29] [30]. Complexity teaching requires an active, learner-centered approach where students and teachers influence each other's emerging understandings [5] [13]. According to Bonk [31], participatory learning is a central concept in the second global transformation-the shift from education that is content based, behaviorally evaluated, and hierarchical to complexity inspired education that is concept-based, emergent, and participatorywhere all people share in each other's learning. He and other leaders are calling for a shift from teacher-centered teaching to student-centered learning [32] [33].

Research evaluating complexity pedagogy is sparse. In some respects the absence of research evaluating complexity pedagogy is surprising given the substantive theory development over the past decade (see for example, [3] [30] [34] [35]. One possible reason may link with the points of disconnect between assumptions of complexity-non-linear change, co-emergent learning, and selforganization-and the assumptions of traditional research that pre-define and predict variables and indicators of change. Relationships, whole human beings who help co-create each other's understandings, and complex realities of interwoven strands and meanings that typify complexity-based pedagogy and discernment are challenging to investigate.

\section{Complexity Pedagogy of the Daagu Platform}

Daagu provides a coherent framework of functions informed by complexity pe- 
dagogy to facilitate student engagement, community dialogue, divergent thinking, creativity, reflection, and emergent learning through difference [26] [27]. Daagu incorporates multiple formats for inquiry—-text, video, image, and audio. The technology was developed at York University by a trans-disciplinary (health, education, and digital media, fine arts) team of educators and technical experts and was funded by the Academic Innovation Fund at York University and the Ontario Centres of Excellence.

The educator in the Daagu platform establishes the liberating-constraints [13] [36] for the course. Liberating constraints are the big ideas or perspectives that set the stage for students' choices of pathways of learning and to help them align their contributions to the curriculum. Daagu leverages different views and experiences in order to challenge assumptions and provoke discussion of issues important to the course of study and student interests. The educator's role in complexity pedagogy involves:

- Setting up the space of engagement by establishing liberating-constraintsthe big ideas that will contain course-relevant perspectives.

- Crafting critical questions that require various views and conceptual approaches-stretching the realm of possibility for student engagement with diverging ideas.

- Encouraging reflection and recursion of ideas that foster learners' ability to organize, combine, and inquire.

- Acknowledging emergent learning for learner awareness and growth.

- Encouraging learners to recognize and reflect on their "aha moments" as expressions of learning.

- Encouraging students to contribute resources and discussions to curriculum.

- Recognizing and identifying patterns of thinking across groups of students or across spans of time so as to provoke learners' insights/thinking.

- Provoking, perturbing, and challenging ideas in order to expose unstated assumptions.

- Helping students make connections to neighboring ideas and/or contexts.

- Helping students make explicit the application of ideas/concepts to their practices and day-to-day life activities.

- Encouraging rigor of thinking through meaningful conversation that is open and emergent with others.

\section{E-Learning and Complexity Pedagogy}

Three graduate nursing faculty at York University chose to pilot complexity pedagogy in the Daagu platform in a full credit course: Theoretical and Philosophical Foundations of Nursing Science, offered in a 12-week term. The sections of the course were capped at 15 masters' level students. A total of 43 students were registered and oriented to the Daagu platform. The masters program at York is a fully online program that uses Moodle to manage student learning. The three educators piloting Daagu had been teaching online with Moodle for more than seven years. The research question addressed in this report is: What does emer- 
gent learning look like in an e-learning platform? Emergent learning has been defined as simply "new" learning by Sims [33] and is widely discussed in complexity pedagogy as connected, distributed, or relational learning that cannot be predicted or controlled because it surfaces amid the conversations and explorations of members of the class or community [34] [37].

\section{Research Design}

The focus of this paper is on qualitative findings and our intent is to describe how students participated in an online course and to address the question of emergent learning. The study received ethical approval from York University's Ethics Review Board. Of the 43 students in all sections, 21 gave informed consent to complete research interviews, surveys, and questionnaires. All students were informed of the overall introduction of the Daagu platform. Upon completion of the course, researchers gathered 400 pages of text-based interactions from the three sections of the graduate nursing course. Initially, seven content areas were clustered from all course sections and were named in order to organize the large amount of text: "aha moments", students' questions to colleagues, student to student learning/discussion, instructor questions to community/students, descriptions of new learning, student expression of feelings/emotions, student contributions to curriculum, and student linking of course content to personal experience. To address the research question about emergent learning, researchers examined content gathered in the two categories of: new learning, and student described "aha moments". Quotes from consenting students are included in this report. Two researchers identified the seven content areas and all three reviewed, selected, and discussed quotes aligned with categories new learning and "aha moments".

Students participating in the current study were introduced to complexity pedagogy in the course syllabus where ideas of emergent learning and engagement were described (see Table 1). Students were introduced to the complexity assumption that exploration and discussion of different views is generative of new insights or "aha moments". These shifting insights and described "aha moments" capture a view of emergent learning as it surfaced in three sections of the graduate nursing course.

It is important to point out here that in the Daagu platform students contribute to the curriculum based on their own learning interests and contexts. All participants in the courses contributed links to papers/articles, TedTalks, YouTubes, and ArtForms (images, poems), that spoke to them and to the discussion at hand. The teacher's role, in a general sense, is to share in the collaboration as a connector, perturber, inquirer, and seeker of difference. For example, if a conversation is happening where students are sharing similar views, the teacher may ask if someone has a different view, or s/he may offer an article that presents a different view than the one being expressed.

All students in the three sections engaged with the beta testing version of the e-learning platform in which there were several technological challenges that 
Table 1. Content from course syllabus.

Course Perspectives: To help organize the ideas to be explored in the course, we have divided the course content into four broad areas, as follows.

1. Philosophical assumptions, science, \& nursing

Description: This perspective concerns how sciences are aligned with various philosophical assumptions that guide the way knowledge is understood and created.

2. Knowledge development, human science, \& nursing

Description: This perspective considers how knowledge has developed in the tradition known as human science, and how human science has developed in nursing. Various schools of thought (e.g., existential phenomenology, critical thinking, social ecology, and others) have informed the development of human science.

\section{Practice \& ethical relating in nursing}

Description: This perspective invites students to consider the various ways ethical relating shows up in nursing practice with persons and groups, and as a leader, researcher, and educator. Ethical relating can be viewed as an interpersonal issue, a policy issue, a research happening, and a political reality.

\section{Controversies \& intersections in nursing science}

Description: In our very complex world there are many different ideas and issues to consider when it comes to nursing science. Controversies reflect the reality that there are many different views and ways of thinking. Intersections help us see the points when ideas collide or come together to make sense. Both controversies and intersections are important to our evolving understanding.

\section{Overview of Teaching-Learning Approach}

Course teaching-learning activities are informed by complexity pedagogy. Complexity pedagogy proposes that all persons in a community of inquiry learn together. Teachers and students come together to engage, share, and question in order to develop personal understandings. Diverse views and different perspectives enable deep learning, and so, in many ways we are all responsible for contributing - not only to our own understanding and growth, but to that of our colleagues and classmates. There are no right and wrong answers in complexity learning. We all have different views and understandings, because our understanding is contextual, historical, and experiential. We are all coming together from a different place to spend time together in a shared quest for insights and emergent learning.

\section{Complexity Pedagogy: Terms and Definitions}

Here are some definitions of ideas (informed by the authors [5] [14] [28] [30] [34]) that describe learners' experiences as part of a collaborative community of inquiry.

Reflection: A process of contemplation about one's thinking and actions in specific situations in order to better understand the pros and cons of different ways of thinking and acting.

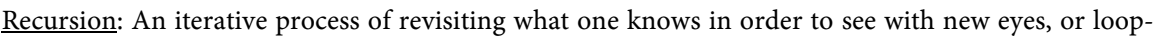
ing back with the intent to discover again.

Emergent Learning: As students and teachers inter-relate, offering different views and posing different questions, new learning emerges in the shifts of understandings and perspectives. All students and teachers can create teachable moments by introducing different ways of thinking about and acting in various situations.

Perturbations: Disruptions of the status quo created by challenging assumptions, providing alternative views, and asking different questions that expand understandings. Perturbations may point out paradox, ambiguity, and critical aspects of familiar ways of knowing.

Diversity: Difference is needed for deep thinking and critical understanding. Seeing only one way misses the complexities of life and learning. When diverse views are shared, new insights often surface and propel thinking and problem-solving in new ways as difference is considered and conversed about.

Non-linearity: Life, living systems, thinking, and responding are all evolving historically, experientially, reflectively, and non-reflectively, in stops and starts, transformative leaps, and sometimes with unexplainable emergence. Change in living systems and processes cannot be controlled in simple formulas or directives. Living systems are continuously evolving in unpredictable ways.

Relationality: This concept indicates the ways people, things, ideas, preferences, and patterns connect and interrelate. An idea can link with many different experiences, an event might link with many memories, and a concept can connect with particular ideas across multiple contexts in a web of relationality. 
were frustrating for both students and faculty. For example, students and faculty could not tell where the most recent posts were and had to search through various discussions to stay on top of conversations. Despite the technological challenges, $80 \%$ of student participants indicated that they found the learning experience engaging and meaningful. Involved faculty (current authors) found the complexity pedagogy enabled deep learning and student involvement that we considered substantially different from our other e-learning experiences over the prior seven years. The remainder of the current report will address the research question on emergent learning.

\section{Findings}

In the analysis of student discussions, emergent learning was clearly identifiable in one of two situations: 1) students describing a (new) change in perspective, attitude, or action that was linked with a particular resource or discussion; and 2) students describing specific "aha moments" or shifts in understanding that were meaningful to them and their learning/practice. Each situation will be described with supporting excerpts from student participants. There were approximately 80 comments/excerpts describing new learning across the three sections of the course. We begin with examples from different course sections of how students described new learning (changes in their perspectives, attitudes, or actions) linked with a specific resource. For example, one student posted the following:

This article by Naef [38] had me thinking after just reading the title. Thinking of bearing witness as a MORAL way of engaging is a wonderful concept. When I tend to think of moral actions in my day they usually involve standing up to a doctor to get my patient appropriate pain meds or letting a family stay well after visitors are supposed to leave. It never occurred to me that the moral action was looking at the patient's face and "taking on an ethical responsibility for the other". Such a powerful concept. Conversely, turning away from another is seen as an act of violence-a decision not to bear witness and instead let them suffer alone. Great article that has forced me to reflect on instances in my practice when I may have turned away. (Course Section 1)

Another student offered the following.

I read an article on postcolonialism written by Holmes, Roy, \& Perron [39]. Authors stated that, "it is essential that different types of knowledge be made accessible to both care providers and recipients in order to break free from nursing's colonial past, which is still grounded in post positivism" (p. 49). When I started nursing I worked in an environment that treated non-White nurses with indifference. Non-White nurses that wanted to survive would ally with the white nurses and would assist in the oppression of non-White nurses. The atmosphere was tense and racism was evident. I feel that I took a back seat in this practice and did not speak up to defend the evident discrimination. There was a ringleader involved in this practice and all her troops followed her lead. Non-White nurses did excellent work, yet were not acknowledged and often given heavy as- 
signments and not empowered in acute situations even though they had the capabilities. I now know, more than ever, that I supported the colonization of nursing by not doing anything about the situation. I've since had dialogue with many nurses who worked with me back then who share the same feelings that I do, and express what that they could have done things much differently. The article goes on to mention that the (de)colonization of nursing is a highly political process. Therefore one must be ready to be a voice while trying to increase the counter-narrative, as mentioned in the article. Nurses must not only recognize that it is within their power to challenge disciplinary colonization, they have an obligation to actively engage in decolonizing actions in order to begin reversing the effects, and I emphasize.... begin. (Course Section 1).

And another,

Thanks for sharing additional ways of knowing that I had not considered before. Evidenced based practice is great but it should not be our only focus. When we put all our focus on one thing we can often lose sight of bigger things. I would like to add another form of knowing that I read about in the article by Doane \& Varcoe [40]. The authors stressed that as nurses we must shift from EBP to inquiry-based practice as it is one way to translate what nurses know and actually do. As an inquirer, the goal is to enter each situation experiencing theoretic and research knowledge anew. We all strive to provide care that is holistic and patient centered, so I will use this information to further develop my skills as a nurse leader and continue to treat each patient as an individual since no two people are exactly alike. Knowledge that I possess is not necessarily going to apply to all my patients/situations. Instead I will listen to my patients and engage them in helping me to learn new things on a daily basis. From reading all the articles this week I came to the conclusion that knowledge is always evolving and we limit ourselves when we stop searching for answers and different ways to do things. (Course Section 2).

And another,

Many times I have relied on knowing what is best for my patients through my EBN practice. This article has helped me look beyond my own thoughts and to realize that there is more then EBN to being a good nurse. One of the ideas that I really appreciated in the Holmes et al., [41] article about the way that the evidence based practice movement has a totalizing perspective that leads us all to look at the world only through that lens. This idea speaks to nurses having the ability to open their thoughts and world positions on what they think are best for the patient. There may not be the same answer for every individual patient, despite what the 'research' shows. (Course Section 3).

One student shared,

One thing in the article Philosophical Inquiry and the Goals of Nursing: $A$ Critical Approach for Disciplinary Knowledge Development and Action [42] that intrigued me was the exemplar discussion of the philosophical inquiry of advocacy. I had always taken it for granted that as a nurse I was a "patient advocate" but had never really stopped to reflect on the meaning of this term for me 
personally or for the profession of nursing as a whole. Using the philosophical taxonomy I have now realized that advocacy encompasses a whole realm of categorizations. I would say that as nurses our responsibility of advocacy most closely resembles one of "professional advocacy" (42, p. 74]. After reading this article I have come to the understanding that in a philosophical inquiry framework it is not enough to take a term such as advocacy at face value, but instead I must ask the reflective questions behind the meaning of advocacy and critically analyze how it fits in to my practice personally and professionally. (Course Section 3).

Another student wrote:

This is a very intriguing article and a thought-provoking discussion! Coming from a science background with my first undergrad study and working in a highly technological environment setting as an RN, I had never thought of questioning the basis of EBP and its significance in nursing practice prior to reading this article. Bolt stated that "Science-as-research enframes us: it sets a limit on what and how we think and how we interact with the world." I agree with this statement as I can attest that I never felt as challenged as I am currently in this course to question and critique the knowledge and assumptions that I carry in this nursing profession!! I definitely see the purpose of utilizing EBP as a clinical tool, but I agree with the article that "EBP be re-situated or reconstructed as a collective and organizational responsibility and not the responsibility of individual nurses in practice" ([43], p. 148). How can our organizations create a work environment that values the non-measurable, and promotes the growth of nursing knowledge as emerging and complex rather than simply relying on "evidence"? (Course Section 1)

\section{Described "Aha Moments" of Emergent Learning}

Students were asked to reflect on their learning and changing understandings throughout the term and reflection on personal views was built into one of the required papers. Students were also asked to take note of and record their insights or "aha moments" as one way to reflect on and map their changing perspectives. Students embraced the "aha moment" idea and recorded more than 70 over the 12 week term. The recorded "aha moments" provide additional insight into how emergent learning shows up in the complexity-based curriculum.

One student noted the following.

I had an "aha moment" that was worthwhile. The YouTube posted, "Alive Inside: Henry's Story" [44] where Henry came alive with music. Music is one of the few activities that involves using the whole brain and Henry had dementia but responded well to music. My patient is like Henry. He loved singing, music, and reading his bible. After discussing the benefits of music with his family and occupational therapist, his family brought in his favourite music and bible passages in spoken narrative. After introducing the music to the patient, there was a great transformation in his overall demeanor; he was smiling again, agitation was gone and he finally slept at nights (Course Section 2). 
And another example:

After reviewing the discussions we had in past weeks I uploaded a picture resource to illustrate one of my "aha moments". Prior to taking this course I believed that evidenced based practice was the gold standard for knowledge. I truly believed that the best research to guide my practice was empirical in nature, since that was emphasized in my undergraduate learning, and I am constantly reminded of this in my work setting. It was enlightening to know that as nurses we can consider the alternatives to truth and knowledge in the aesthetic work we do in practice. I have now shifted my thinking to the possibility that there is no concrete truth to what is considered knowledge; instead there is a world of possibilities that we must explore. Whether it be inquiry-based, socio-political, moral-ethical or intuitive knowledge I must open my mind to different ways of knowing as it is essential if I want to provide holistic care from a human science perspective. (Course Section 3).

Another student wrote:

What I found to be particularly insightful about her (a nurse author Naef,) story [38], was despite the fact that she was unable to get her patient's pain adequately managed, the patient, in all his suffering, was able to utter the words, "it's just enough that you are here". This was my "aha moment" because I think that we can probably all relate to a time in our career when we felt helpless. I think the YouTube clip also stresses the importance of taking the time to bear witness to our patients. As so powerfully demonstrated in her story, bearing witness can sometimes be the most courageous and respectful response to alleviate suffering, aloneness, and vulnerability [38] (Course Section 2).

One student shared:

Emma Goldman is one of my favourite activists from the early 20th centuryalthough I cannot say I agree with all her tactics she was a strong, committed, dedicated feminist of courage who fought to resist the status quo particularly around gender politics-my "aha moment" came after immersing myself today in several critiques of evidence based nursing (EBN) - and ending up feeling shocked that I have never considered the political agendas behind it-now, of course, the light has come on-EBP as part of the neoliberal agenda to rationalize health services, of course it is! Also surprising to me (exciting too) is the call in Holmes et al. [39] article to resist EBN, to overthrow the "tyranny" of exclusive, dominant ideologies-but is there a culture of resistance in nursing? I have my doubts, but then again, this article surprised me in its radical analysis. (Course Section 3).

And another:

The articles about understanding women living with pain [45] [46] were a real eye opener for me, an "aha moment" even, into my own bias and opinions affecting my practice and how I treat certain people. The aspect I found most interesting to note, which I had not previously considered, was the correlation between physical abuse and medically un-diagnosable pain. I know in my experiences with patients who have chronic pain issues or have the diagnosis of fi- 
bromyalgia, for example, they are immediately stigmatized. Doctors and nurses don't take these people seriously in the emergency setting. Even I have held similar views. This article has forced me to reconsider the life struggles people have to endure and how they may have negatively impacted their health. Just because medicine doesn't understand it yet doesn't negate the fact that stress (physical, emotional, biological, molecular) has a negative impact on the human body. (Course Section 1).

While a good reading or interesting idea always have the potential to produce new insights for students, in the Daagu platform students followed their own learning interests without an authority telling them what ideas or resources to pursue. One can see in the students' comments that their insights during the course changed about who they are as persons and as professionals. Complexivists calls on educators and researchers to look for relationships and patterns of relationships. For instance, sharing and collaborating about diverging ideas may generate new patterns of learning. The quotes above offer insights to better understand how learning happens and how insights emerge with diverse views in an environment that does not have an authority voice. Students demonstrated deep and critical learning in their questions and explicit understandings. We believe the quality of engagement and discussion was amplified in the Daagu platform in new patterns of collaboration and co-discovery. The diversity of thought in complexity e-learning makes it a particularly fertile learning environment.

\section{Discussion}

Our findings contribute to the discussion about complexity pedagogy and its possibilities for facilitating student engagement, critical thinking, and emergent learning. In order to connect with other conversations about the efficacy of complexity pedagogy [28] [47], we also organize the discussion of findings on emergent learning with Davis, Sumara, and Luce-Keplar's [32] necessary conditions for emergence and new possibilities. The necessary conditions are internal diversity, internal redundancy, neighbor interactions, and decentralized control. We begin with a consideration of internal diversity and its connection to emergent learning in our findings.

\section{Internal Diversity}

As described above, student participants in this study were introduced to complexity thinking and to the guiding belief that every student's experience and different perspective contributes to the learning community. Internal diversity affiliated with student expressions of difference was thus facilitated by the guiding pedagogy and the educator's explicit valuing of difference. Course directors aligned with the view that expression of diversity is a source of intelligence [48] and that the choice to value and recognize the limits of one's and others' knowledge promotes a critical consciousness [49]. The importance of having different ideas mingle and mix can be traced back to Aristotle and the processes of ex- 
pressing and interrogating different ideas is a core belief of democratic societies [50]. Our findings show that students did engage with, and express different perspectives and that diverging views facilitated emergent learning in the Daagu space. For example, recall the students who had not considered that different ways of knowing (ethical, aesthetic, theoretical) can inform nursing practice because their prior education had privileged evidence-based knowledge. Or one student who had not previously considered the role of poverty in self-care and public health. Other authors addressing complexity and constructivist pedagogies in mobile and face-to-face formats report on the relationship between diversity and new learning [47] [51] [52] [53]). De Waard et al., [47] reported that their participants indicated they learned more from course concepts when students from different disciplines expressed their views. More than $90 \%$ of 40 participants in the de Waard et al., study responded that they learned from people with different areas of expertise. Herrington, Reeves, and Oliver [51] identify engagement with difference and different perspectives essential for authentic learning environments and for helping students to develop deep and critical thinking about complex issues. Engagement with different views is also a foundation for collaborative learning which has demonstrated improved outcomes and enhanced learning for students [54].

\section{Internal Redundancy}

Internal redundancy refers to the necessary similarities that facilitate co-activity and communication among participants [34]. In the three sections of the nursing course being addressed here, students were all registered nurses starting in a graduate level, fully online master's program at a Canadian university. The students shared their profession and place in the program. They were all able to understand and communicate in English. The course syllabus laid the ground for the shared definitions of terms and expectations of students and faculty.

Internal redundancies (similarities) complement the diversities and both facilitated the emergent learning in the courses. For example, students shared their common background of a $\mathrm{BScN}$, required for entry to the program, but their experiences of content, philosophy, and values were sufficiently diverse to provoke new learning. More specifically, some students came from baccalaureate programs that emphasized the biological and clinical aspects of nursing while others contributed more human science based, experiential understandings of nursing. The nursing students also had diverse practice experiences from acute, emergent care to community-based and street health. Each influenced the other as shown in student "aha moments" and expressed learning.

Internal redundancy links with research conducted on the phenomenon of common ground, as a necessary requirement for collaboration, learning, and complex problem solving [54] [55] [56]. Kuziemsky and O’Sullivan [55] offer a model that describes development of common ground over time and refer to common ground as a dynamic and evolving requirement for collaboration. Arkoudis et al., [54] wanted to increase opportunities for students to learn from 
each other, to explore differences, and expand perspectives and common ground. Researchers focused on enhancing interaction and engagement, especially for students from different cultures and geographic areas. Focus groups with academics and students across three universities generated themes consistent with complexity pedagogy. Specifically, researchers recommended that faculty design curriculum to facilitate engagement with diverse perspectives in order to increase quality of learning. Research supports then that common ground and internal redundancy can be attended to in order to complement the diversity and enhance learning.

\section{Neighbour Interactions}

Davis, Sumara, and Luce-Kaplar [34] propose that learning is enhanced when specific processes or structures facilitate the rubbing and mixing of different ideas, questions, assumptions, beliefs, and scenarios. Neighbouring ideas need to engage and co-exist in a space or conversation in order to both stretch the borders of possibility by shining light on difference and to increase the opportunities for new insights as neighboring ideas connect and collide. This is one of the roles of the educator in the Daagu platform - to facilitate the expression of different views.

Research by De Waard et al. [47] conducted with 40 participants in a MOOC affirmed that participants, offered help, critiqued, and supported other MOOC participants but there was no specific mention of the role of difference and learning. In our research with the graduate nursing students, participants could start new discussions when emergent ideas were sparked, there were multiple instances of student-to-student help with ideas and extension of ideas as students began to see how ideas from one context could be considered and developed in a different context. This is consistent with research by Chang, Sung, \& Lee [57] who explored inquiry-based and collaborative learning with first year university students. These authors reported that: "Ninety-four percent of the students $(n=17)$ agreed that sharing information collected on the web and their personal ideas helped them clarify what they really think. Information sharing mentioned in this study included sharing of products (concept maps), data (notepads), and ideas (dialogue and discussion). The students' favourite form of sharing was dialogue and discussion, followed by the content of notepads, and, finally, their concept maps" (p. 65).

In some ways the translation of ideas from one context to another, and the understanding that concepts can make sense in one context but not in another, relates to the insights of author Nicolescu [58]. Nicolescu developed a method for transdiciplinarity and a new way of thinking about levels of reality, knowledge, and human experience. Understanding that ideas shift in meaning and possibility across time and across contexts helps to deepen learning. Our findings show that as students began to engage with ideas across contexts, it became easier for them to see how multiple ideas and knowledges are relevant, or not, when considered in light of different patient contexts or different time frames of 
health and care. For example, simple causality makes sense when considering the relationship between hand washing and spread of bacteria, but fails to make sense when considering how human beings make decisions or grieve a loss. Embracing levels of reality and the continuity and discontinuity of ideas and concepts expands possibilities for new understanding and infinite questions [58].

Student participants in our course sections embraced the generative role of questions and often posed additional questions when classmates opened up topics for inquiry. Because students contributed to the curriculum with their own quests, resources, and questions to classmates, they were numerous instances across the three sections of the course that show both the power of questions over answers, as well as the cascading influence of questions and different ideas. Students' multiple contributions to the curriculum using various papers, YouTubes, TedTalks, and poems prompts us to the next necessary condition for emergence, decentralized control [34].

\section{Decentralized Control}

It was essential to create the openness for student additions to the curriculum and their expressions of personal experiences by establishing safe space that had no authoritative figure or presence directing decisions and making judgments of right and wrong thinking. If you recall, from the outset with the syllabus, students were introduced to complexity thinking and how it would guide our relating in the e-learning platform. The students knew that we (educators) wanted to engage with different ideas and to hear how students understood ideas in their practices and personal lives. These students embraced the opportunity to express, contribute, question, and explore. The curriculum grew exponentially in the Daagu platform as students experienced the freedom to contribute to the learning community.

Participants in the MOOC research de Waard et al., study, [47] also had the freedom to contribute to the curriculum of the MOOC and to express and start discussions. The majority of these participants felt connected and engaged with others in the MOOC. Similar to findings in our study, participants collaborated and contributed to learning of fellow classmates. Freedom or student control plays an important role in how learning happens in educational arenas-including and perhaps especially in e-learning [59]. Peters and Araya [59] describe how society has moved from the simplistic linear mode of production (train the trainer) to distributed or many-to-many production-networks are now the source of all kinds of production in our personal and work lives.

In our course sections using the complexity e-learning platform, students contributed dozens of resources to the curriculum. Resources that any one educator may never have encountered or thought important. The student-to-student engagement increased the networks for new learning in unpredictable ways. Further, in the e-learning platform, students also had access to the resources used by faculty and students in other course sections, greatly increasing the possible connections for engaging, learning, and growth while pursuing their 
inquiries according to their own interests. We propose it would not have been possible or desirable to try to control and harness the students' learning experiences. The student networks that formed generated far more possibilities for meaningful learning.

\section{Engagement and Patterns of Emergent Learning}

What does student engagement look like? In the complexity e-learning platform called Daagu, student engagement included the following:

- disclosing personal thoughts and experiences to classmates

- questioning one's beliefs and assumptions

- offering resources and helpful links to the community

- conversing about difficult and challenging situations

- reflecting on insights and "aha moments"

- describing changes in understanding, attitudes, and actions

- exploring different ways of perceiving, thinking, and being

- understanding the continuity and discontinuity of knowledge across levels and contexts

An extensive review of student engagement-its history, definitions, scope, and role in high quality education, from a traditional research perspective, can be accessed in the article by McCormick, Kinzie, \& Gonyea [60]. In their consideration of a more "sophisticated" consideration of student engagement these authors suggest that there are patterns of engagement that exist and these patterns influence outcomes. We concur that student engagement is important and educators/institutions have a responsibility to create spaces for meaningful student engagement to happen. In the Daagu platform engagement was witnessed as students took control of their own exploring and learning and sharing. Students were passionate about sharing what and how they were learning. We know the learning was meaningful because the students elaborated differences in their thinking and acting. Students expressed surprise and change with their insights.

At this very early point in the exploration of complexity-based e-learning and student engagement, we suggest that a pattern of student engagement emerged in our courses and the complexity pedagogy was embraced by most students. One dominant pattern of emergence was the engagement with the "aha moment" concept and the expression of when, how, and what related to the moments of insight. Details of how students engaged with the curriculum and their specific "aha moments" will be described in a different publication.

\section{Limitations of the Study}

Complexity research in e-learning is just beginning and our explication of emergent learning in three sections of a graduate nursing course offers one place to start a dialogue about what difference complexity pedagogy can make. In this time when formal education is facing intense challenges relating to relevance and sustainability, educators need to seriously reflect on the effectiveness of teaching methods and modes of delivery. This report is intended to contribute to 
the conversation of complexity and possibility. The descriptions of emergent learning presented here were from predominantly female students in a nursing program. Research with mixed gender participants is needed. The three authors are colleagues and have worked together for numerous years so there was a high degree of trust and collaboration. Ideally, we would like to compare student experiences in course sections where faculty use different pedagogical approaches and e-learning platforms to better understand emergent learning. Comparative studies may be possible as more educators adopt the e-learning mode of delivery. We also recognize that complexity pedagogy is probably not be a good fit for faculty who value control and authority. Educators must be willing to take the risk to trust students and to let lose the distributed learning of a collective and collaborative group. The first author also led the team that created the Daagu platform and has an interest in its adoption as an alternative e-learning platform.

\section{Acknowledgements}

Authors gratefully acknowledge funding from the Academic Innovation Fund at York University and the Ontario Centres of Excellence.

\section{References}

[1] Mureşan, M. (2012) Web Media Challenges University Educational Processes. Euromentor Journal, 3, 70-83.

[2] Dabbagh, N. and Kitsantas, A. (2012) Personal Learning Environments, Social Media, and Self-Regulated Learning: A Natural Formula for Connecting Formal and Informal Learning. Internet and Higher Education, 15, 3-8.

https://doi.org/10.1016/j.iheduc.2011.06.002

[3] Doll, W.E. (1993) A Post-Modern Perspective on Curriculum. In: Soltis, J.F., Ed., Advances in Contemporary Educational Thought Series, Teachers College, Columbia University, 30-154.

[4] Garrison, D.R. (1993) A Cognitive Constructivist View of Distance Education: An Analysis of Teaching-Learning Assumptions. Distance Education, 14, 199-211. https://doi.org/10.1080/0158791930140204

[5] Ricca, B. (2012) Beyond Teaching Methods: A Complexity Approach. Complicity, 9 , 31-51.

[6] Tyler, R.W. (1950) Basic Principles of Curriculum and Instruction. University of Chicago, Chicago.

[7] Downs, S. (2012) Connectivism and Connective Knowledge. Essays of Meaning and Learning Networks. National Research Council, Canada.

[8] Cole, M.T., Shelley, D.J. and Swartz, L.B. (2014) Online Instruction, E-Learning, and Student Satisfaction: A Three Year Study. The International Review of Research in Open and Distributed Learning, 15, 112-131. https://doi.org/10.19173/irrodl.v15i6.1748

[9] Garrison, D.R. (2007) Online Community of Inquiry Review: Social, Cognitive, and Teaching Presence issues. Journal of Asynchronous Learning Networks, 11, 61-72.

[10] Garrison, D.R. and Arbaugh, J.B. (2007) Researching the Community of Inquiry Framework: Review, Issues, and Future Directions. Internet and Higher Education, 10, 157-172. https://doi.org/10.1016/j.iheduc.2007.04.001 
[11] Siemens, G. (2004) Connectivism: A Learning Theory for a Digital Age. http://www.itdl.org/journal/jan 05/article01.htm

[12] Siemens, G. and Downes, S. (2008) Connectivism \& Connected Knowledge. http://nsuworks.nova.edu/innovate/vol5/iss1/6

[13] Fenwick, T. (2003) Reclaiming and Re-Embodying Experiential Learning through Complexity Science. Studies in the Education of Adults, 35 123-141. http://www.researchgate.net/publication/233587255 https://doi.org/10.1080/02660830.2003.11661478

[14] Larsson, J. and Dahlin, B. (2012) Educating far From Equilibrium: Chaos Philosophy and the Quest for Complexity in Education. Complicity, 9, 1-14.

[15] Morgan, D. and Adams, J. (2009) Pedagogy First: Making Web Technologies Work for Soft Skills Development in Leadership and Management Education. Journal of Interactive Learning Research, 20, 129-155.

[16] Kop, R., Fournier, H. and Mak, J.S.F. (2011) A Pedagogy of Abundance or a Pedagogy to Support Human Beings? Participants Support on Massive Open Online Courses. The International Review of Research in Open and Distance Learning, 7, 74-93. http://www.irrodl.org/index.php/irrodl/index https://doi.org/10.19173/irrodl.v12i7.1041

[17] Wilson-Doenges, G. and Gurung, R.A.R. (2013) Benchmarks for Scholarly Investigations of Teaching and Learning. Australian Journal of Psychology, 65, 63-70. https://doi.org/10.1111/ajpy.12011

[18] Abrami, P.C., Bernard, R., Wade, A., Schmid, R.F., Borokhovski, E., Tamin, R. and Peretiatkowicz, A. (2008) A Review of E-Learning in Canada: A Rough Sketch of the Evidence, Gaps and Promising Directions. Canadian Journal of Learning and Technology, 32, 119-139.

http://cjlt.csj.ualberta.ca/index.php/cjlt/article/viewArticle/27 https://doi.org/10.21432/t2qs3k

[19] Finger, G. (2014) eLearning: Exploring Digital Futures in the 21st Century. Education Sciences, 4, 209-212. https://doi.org/10.3390/educsci4030209

[20] Lai, A. and Savage, P. (2013) Learning Management Systems and Principles of Good Teaching: Instructor and Student Perspectives. Canadian Journal of Learning and Technology, 39, 1-20.

[21] Means, B., Bakia, M. and Murphy, R. (2014) Learning Online: What Research Tells Us about Whether, When and How. Routledge Taylor \& Frances, New York.

[22] Rassmussen, K., Belisario, J.M., Wark, P.A., Molina, J.A., Loong, S.L., Cotic, Z., et al. (2014) Offline E-Learning for Undergraduates in Health Professions: A Systematic Review of the Impact on Knowledge, Skills, Attitudes and Satisfaction. Journal of Global Health, 4, Article ID: 010405. https://doi.org/10.7189/jogh.04.010405

[23] Venkatesh, V., Croteau, A.M. and Rabah, J. (2014) Perceptions of Effectiveness of Instructional Uses of Technology in Higher Education in an Era of Web 2.0. 47 th Hawaii International Conference on System Sciences, Waikoloa, 6-9 January 2014, 110-119. https://doi.org/10.1109/hicss.2014.22

[24] Boling, E.C., Hough, M., Krinsky, H., Saleem, H. and Stevens, M. (2012) Cutting the Distance in Distance Education: Perspectives on What Promotes Positive, Online Learning Experiences. Internet and Higher Education, 15, 118-126. https://doi.org/10.1016/j.iheduc.2011.11.006

[25] Price, L. and Kirkwood, A. (2013) Using Technology for Teaching and Learning in Higher Education: A Critical Review of the Role of Evidence in Informing Practice. Higher Education Research and Development, 33, 549-564. 
https://doi.org/10.1080/07294360.2013.841643

[26] Mitchell, G.J., Cross, N., George, O., Hynie, M., Kumar, K., Owston, R., Sinclair, D. and Wickens, R. (2016) Complexity Pedagogy and E-Learning: Emergence in Relational Networks. International Research in Higher Education, 1, 206-215.

http://www.sciedupress.com/journal/index.php/irhe/article/view/9136

[27] Mitchell, G.J., Pilkington, B., Jonas-Simpson, C.M., Daiski, I., Cross, N.L., Johnston, N. and Tang, S.Y. (2016) Nursing Education and Complexity Pedagogy: Faculty Experiences with an E-Learning Platform. Journal of Nursing Education and Practice, 6, 60-68. https://doi.org/10.5430/jnep.v6n5p60

[28] Doll, W.E., Fleener, M.J., Truit, D. and St. Julien, J. (2008) Chaos, Complexity, Curriculum, and Culture: A Conversation. Peter Lang, New York.

[29] Jacobson, M.J. and Wilensky, U. (2006) Complex Systems in Education: Scientific and Educational Importance and Implications for the Learning Sciences. Journal of Learning Science, 15, 11-34. https://doi.org/10.1207/s15327809jls1501 4

[30] Mason, M. (2008) Complexity Theory and the Philosophy of Education. In: Mason, M., Ed., Complexity Theory and the Philosophy of Education, Wiley-Blackwell, Malden, 1-15. https://doi.org/10.1002/9781444307351.ch1

[31] Bonk, C.J. (2009) The World Is Open: How Web Technology Is Revolutionizing Education. John Wiley \& Sons, Hoboken. http://www.editlib.org/p/31963

[32] Davis, B. and Sumara, D.J. (2006) Complexity and Education: Inquiries into Learning, Teaching, and Research. Psychology Press, Philadelphia.

[33] Sims, R. (2014) Design Alchemy: Transforming the Way We Think about Learning and Teaching. Springer, New York. https://doi.org/10.1007/978-3-319-02423-3

[34] Davis, B., Sumara, D. and Luce-Kapler, R. (2008) Engaging Minds: Changing Teaching in Complex Times. 2nd Edition. Routledge, New York.

[35] Friesen, S. and Clifford, P.A. (2006) Curriculum in Abundance. In: Jardine, D.W., Ed., Doing Educational Research: A Handbook, Psychology Press, Philadelphia.

[36] Davis, B. and Sumara, D. J. (1997) Cognition, Complexity, and Teacher Education. Harvard Educational Review, 67, 105-126. https://doi.org/10.17763/haer.67.1.160w00j113t78042

[37] Newel, C. (2008) The Class as a Learning Entity (Complex Adaptive System): An Idea from Complexity Science and Education Research. SFU Educational Review, 2, 5-17.

[38] Naef, R. (2006) Bearing Witness: A Moral Way of Engaging in the Nurse-Person Relationship. Nursing Philosophy, 7, 146-156. https://doi.org/10.1111/j.1466-769X.2006.00271.x

[39] Holmes, D., Roy, B. and Perron, A. (2008) The Use of Postcolonialism in the Nursing Domain: Colonial Patronage, Conversion, and Resistance. Advances in Nursing Science, 31, 42-51. https://doi.org/10.1097/01.ANS.0000311528.73564.83

[40] Doane, G.H. and Varcoe, C. (2008) Knowledge Translation in Everyday Nursing: From Evidence Based to Inquiry-Based Practice. Advances in Nursing Science, 31, 283-295. https://doi.org/10.1097/01.ANS.0000341409.17424.7f

[41] Holmes, D., Perron, A. and O’Byrne, P. (2006) Evidence, Virulence, and the Disappearance of Nursing Knowledge: A Critique of the Evidence-Based Dogma. Worldviews on Evidence-Based Nursing, 3, 95-102. https://doi.org/10.1111/j.1741-6787.2006.00058.x

[42] Grace, P.J. and Perry, D.J. (2013) Philosophical Inquiry and the Goals of Nursing: A Critical Approach for Disciplinary Knowledge Development and Action. Advances 
in Nursing Science, 36, 64-79. https://doi.org/10.1097/ANS.0b013e3182901921

[43] Mitchell, G.J. (2013) Implications of Holding Ideas of Evidence-Based Practice in Nursing. Nursing Science Quarterly, 26, 143-151. https://doi.org/10.1177/0894318413477139

[44] Sundance Film Festival (2014) Alive Inside: A Story of Music \& Memory FeaturetteDocumentary HD. https://youtu.be/8HLEr-zP3fc

[45] Malterud, K. (1999) Understanding Women in Pain: New Pathways Suggested by UME Researchers: Qualitative Research and Feminist Perspectives. Scandinavian Journal of Primary Health Care, 16, 195-198. https://doi.org/10.1080/028134398750002945

[46] Werner, A. and Malterud, K. (2003) It Is Hard Work Behaving as a Credible Patient: Encounters between Women with Chronic Pain and Their Doctors. Social Science \& Medicine, 57, 1409-1419. https://doi.org/10.1016/S0277-9536(02)00520-8

[47] De Waard, I., Abajian, S., Gallagher, M.S., Hogue, R., Keskin, N., Koutropoulos, A. and Rodriguez, O.C. (2011) Using mLearning and MOOCs to Understand Chaos, Emergence, and Complexity in Education. The International Review of Research in Open and Distance Learning, 12, 94-115. https://doi.org/10.19173/irrodl.v12i7.1046

[48] Davis B. and Sumara D. (2012) Fitting Teacher Education in/to/for an Increasingly Complex World. Complicity, 9, 30-40.

[49] Alhadeff-Jones, M. (2014) Learning Disorders: From a Tragic to an Epic Perspective on Complexity. Complicity, 9, 1-5.

[50] Bridges, D. and Watts, M. (2007) www.thedevelopmentofknowledge.net. In: Smeyers, P. and Depaepe, M., Eds., Educational Research: Networks and Technologies, Springer, Berlin, 15-32. https://doi.org/10.1007/978-1-4020-6613-9 2

[51] Herrington, J., Reeves, T.C. and Oliver, R. (2014) Authentic Learning Environments. Springer, New York, 401-412.

[52] Osberg, D., Biesta, G. and Cilliers, P. (2008) From Representation to Emergence: Complexity's Challenge to the Epistemology of Schooling. Education Philosophy and Theory, 40, 213-227. https://doi.org/10.1111/j.1469-5812.2007.00407.x

[53] Pecka, S.L., Kotcherlakota, S., Berger, A.M. and Aprn-Cns, A.O.C.N.S. (2014) Community of Inquiry Model: Advancing Distance Learning in Nurse Anesthesia Education. AANA Journal, 82, 213.

[54] Arkoudis, S., Watty, K., Baik, C., Yu, X., Borland, H., Chang, S., Pearce, A., et al. (2013) Finding Common Ground: Enhancing Interaction between Domestic and International Students in Higher Education. Teaching in Higher Education, 18, 222-235. https://doi.org/10.1080/13562517.2012.719156

[55] Kuziemsky, C.E. and O’Sullivan, T.L. (2015) A Model for Common Ground Development to Support Collaborative Health Communities. Social Science \& Medicine, 128, 231-238. https://doi.org/10.1016/j.socscimed.2015.01.032

[56] Kuziemsky, C.E. and Varpio, L. (2010) Describing the Clinical Communication Space through a Model of Common Ground: "You Don't Know What You Don't Know".

[57] Chang, K.E., Sung, Y.T. and Lee, C.L. (2003) Web-Based Collaborative Inquiry Learning. Journal of Computer Assisted Learning, 19, 56-69. https://doi.org/10.1046/j.0266-4909.2003.00006.x

[58] Nicolescu, B. (2014) Methodology of Transdisciplinarity. World Futures, 70, 186199. https://doi.org/10.1080/02604027.2014.934631

[59] Peters, M. and Araya, D. (2007) Networks, Information Politics and the New Para- 
digm of Social Production. In: Smeyers, P. and Depaepe, M., Eds., Educational Research: Networks and Technologies, Springer, Berlin, 33-42.

https://doi.org/10.1007/978-1-4020-6613-9 3

[60] McCormick, A.C., Kinzie, J. and Gonyea, R.M. (2013) Student Engagement: Bridging Research and Practice to Improve the Quality of Undergraduate Education. In: Paulsen, M.B., Ed., Higher Education: Handbook of Theory and Research, 28, Springer, Berlin, 47-92. https://doi.org/10.1007/978-94-007-5836-0 2

Submit or recommend next manuscript to SCIRP and we will provide best service for you:

Accepting pre-submission inquiries through Email, Facebook, LinkedIn, Twitter, etc. A wide selection of journals (inclusive of 9 subjects, more than 200 journals) Providing 24-hour high-quality service User-friendly online submission system Fair and swift peer-review system Efficient typesetting and proofreading procedure Display of the result of downloads and visits, as well as the number of cited articles Maximum dissemination of your research work

Submit your manuscript at: http://papersubmission.scirp.org/ Or contact ojn@scirp.org 